Original article

\title{
Smokeless tobacco use among women in northeastern states, India: A study of spatial clustering and its determinants using National Family Health Survey-4 data
}

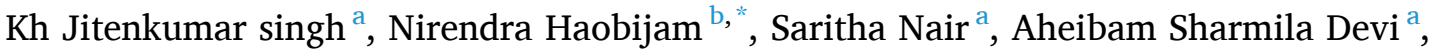 \\ Sagolsem Roshan Singh ${ }^{a}$, Meena Hijam ${ }^{a}$, Nongzaimayum Tawfeeq Alee ${ }^{a}$, Saurabh Sharma ${ }^{a}$, \\ Vijit Deepani $^{a}$, Lucky Singh ${ }^{\text {a }}$, M. Vishnu V. Rao ${ }^{\text {a }}$ \\ ${ }^{a}$ ICMR-National Institute of Medical Statistics, New Delhi, 110029, India \\ b Jawaharlal Nehru Institute of Medical Sciences, Imphal, Manipur, 795005, India
}

\section{A R T I C L E I N F O}

\section{Keywords:}

Binary logistic

Cross-sectional

Hotspot analysis

Spatial clustering

Prenatal health

\begin{abstract}
A B S T R A C T
Background: Use of tobacco, especially smokeless tobacco have characterised as highly prevalent among women, and also the mode of using smokeless tobacco varies based on geographic location, ingredient availability, cultural/societal norms, and personal preferences. Therefore, this study examines the prevalence and social determinants of use of smokeless tobacco among women in NE India. Further, it also identifies the cluster and district hotspots of smokeless tobacco prevalence.

Methods: We analysed a nationally representative data of NFHS-4, covering 93,409 eligible women aged 15-49 years from a survey of representative households from NE states, India. Descriptive statistics, chi-square, binary logistic and log-binomial regression were employed to analyse the data by using STATA software 13.1. Spatial clustering analysis and hotspot analysis were carried out using R-library.

Findings: The prevalence of SLT use among women in NE states, India is $23 \%$. Mizoram $(47.8 \pm 1.2)$ shows the highest prevalence of SLT use, followed by Manipur (46.1 \pm 0.7$)$. It increases concomitantly with age among women. Social determinants like marital status (divorced/widowed), low educational level and residence (urban) were observed to be associated with smokeless tobacco use. Out of the 4032 clusters used in the analysis, 949 clusters were showed as hotspots.

Conclusion: The existing implementation of tobacco control programs and policies in the NE states needs to be evaluated. Owing to the geographical barriers and cultural differences, there is a need to explore the influences unique to these regions, which can further strengthen tobacco control measures. Targeted and tailored intervention within the identified hotspots can be beneficial.
\end{abstract}

\section{Introduction}

Among adults, males generally have higher rates of smokeless tobacco use than females, however, in some countries, such as Bangladesh, Thailand, Cambodia, Malaysia, Vietnam, South Africa, Mauritania, Sierra Leone, and Barbados, use among women is similar to, or higher than use among men. ${ }^{1}$ According to Global Adult Tobacco Survey 2016-17 (GATS-2), Ministry of health and family welfare, Government of India,
$12.8 \%$ women in India consume smokeless tobacco regularly either daily or occasionally. The number of women using tobacco in 2018 was 244 million, and by 2025, there would be 32 million fewer women tobacco users, and most gains are being made in low-and middle-income countries. $^{2}$

Smokeless tobacco use can lead to gum and mouth diseases ${ }^{3,4}$ as it contains carcinogens and exposes to the risks of leucoplakia including precancerous lesion and oral cancer. For women, the use of smokeless

\footnotetext{
* Corresponding author. Department of Community Medicine, Jawaharlal Nehru Institute of Medical Sciences, Porompat, Imphal, Manipur, 795005, India.

E-mail addresses: jitensinghkh@gmail.com (K. Jitenkumar singh), hnirendra10@gmail.com (N. Haobijam), saritha_nair@yahoo.co.uk (S. Nair), sharmila. aheibam@gmail.com (A. Sharmila Devi), roshan.sagolsem@yahoo.in (S. Roshan Singh), meenahijam19@gmail.com (M. Hijam), stan9290marsh@gmail.com (N. Tawfeeq Alee), saurabhpransharma@gmail.com (S. Sharma), ideepani@rediffmail.com (V. Deepani), lucky.5bhu@gmail.com (L.Singh), nims.director@icmr. gov.in (M.V.V. Rao).
} 
Prevalence of any types of tobacco use among women, India, NFHS 4 (2015-16)

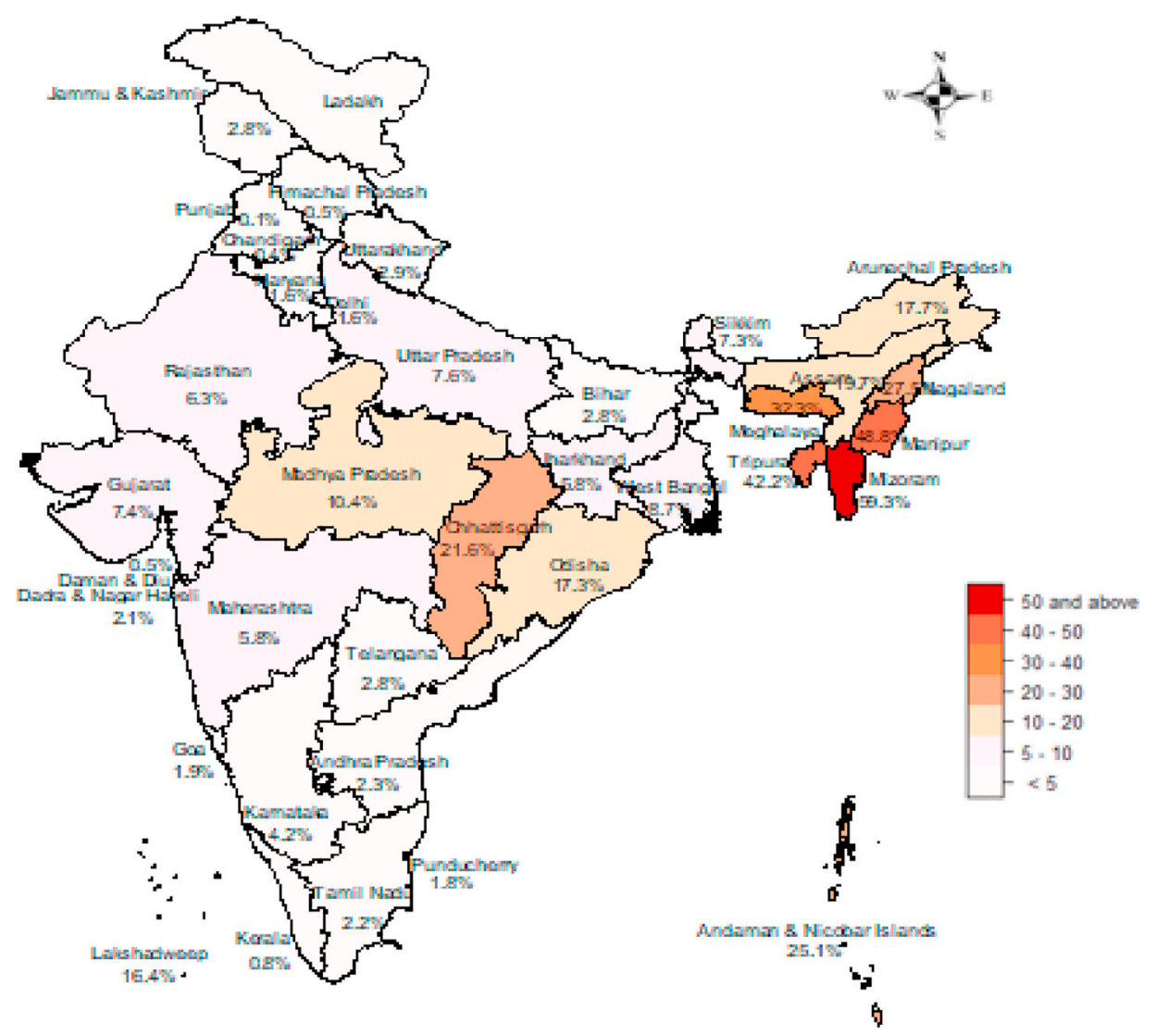

Fig. 1. Prevalence of any types of tobacco use among women, India.

tobacco during pregnancy increases the risk of premature delivery and stillbirth. ${ }^{5}$

So prolonged use of smokeless tobacco can increase heart rate, and also believed to contribute to cardiovascular (heart) diseases including coronary artery disease, ${ }^{3,5}$ high blood pressure and increase cardiovascular mortality.

The Cigarettes and Other Tobacco Products Act (COTPA, 2003) ${ }^{6}$ is the principal comprehensive law governing tobacco control which regulates production, trade and distribution of tobacco products in India. To strengthen implementation of COTPA, the National Tobacco Control Programme (NTCP) is being implemented by Government of India through a three-tiered structure, i.e. (a) National Tobacco Control Cell (b) State Tobacco Control Cell and (c) District Tobacco Control under the National Health Mission (NHM) for effective implementation and monitoring of anti-tobacco laws and initiatives. ${ }^{7}$ Apart from these initiatives, the NTCP also has set up cessation centres and tobacco product testing laboratories at the district level in all states. Despite the existing act and tobacco control policies and related research capacity, the use of tobacco among women is very high in the northeast (NE) India. The NE region comprises of eight small states, namely, Arunachal Pradesh, Assam, Manipur, Meghalaya, Mizoram, Nagaland, Sikkim and Tripura, sharing international borders with China, Bhutan, Bangladesh and Myanmar. The north-eastern region of India is characterized by hilly terrain, agrarian economy, poor infrastructure and inhabited by several ethnic communities.

Fig. 1 showed the prevalence of any types of tobacco use among women in India, and higher prevalence was shown in North-eastern States. In NE region, tobacco is available in a variety of different types and brands, e.g., bidi, gutkka, khaini, pan masala, tuibur, hookah, cigarettes etc. $^{8}$ and also the form of consumption varies from place to place. Use of any types of tobacco among women was high in Mizoram (59\%) and Manipur (49\%) than other remaining states in NE (Fig. 2). ${ }^{9}$ During three rounds of NFHS (1998-99, 2005-06 and 2015-16), use of tobacco among women increased in Manipur (20\%, 40\% \& 49\%); however, the similar prevalence in time prevailed in Meghalaya (28\%, $32 \%$ \& $32 \%$ ) with similar trend at comparatively higher prevalence in Mizoram (61\%, 61\% \& 59\%) (Fig. 2). In all north-eastern states combined, the prevalence of use of any types of tobacco among women was shown decreasing from NFHS 3(2005-06) to NFHS 4 (2015-16), that is, $32 \%-25 \%$ (Authors' estimated, figure not shown in the table). Given the foregoing alarming scenario of a high prevalence of use of tobacco, particularly smokeless tobacco use among women, high incidence rates of cancer attributable to tobacco, and also the mode of smokeless tobacco use varies based on geographic location, ingredient availability, cultural/societal norms, and personal preferences; therefore, there is an urgent need to assess the usage pattern and spatio-social determinants of use of smokeless tobacco among women in the northeast (NE) India. The findings of such study shall provide policy inputs based on context-specific for amendment and strengthening COTPA and NTCP at the regional and district level. An effective means to address the public health emergency of dealing with a high incidence of cancer in the region is curtailed use of tobacco aimed at improving quality and longevity of life of indigenous people of NE India. On the basis of recent rich unit level data about the use of smokeless tobacco from household surveys, it is proposed to assess the prevalence of use of smokeless tobacco among women in the reproductive age groups and find significant determinants of use of smokeless tobacco among women in NE India. The study shall not only enrich the literature on public health research 


\section{Prevalence of any types of tobacco use among women in northeastern states, India, 2015-16}

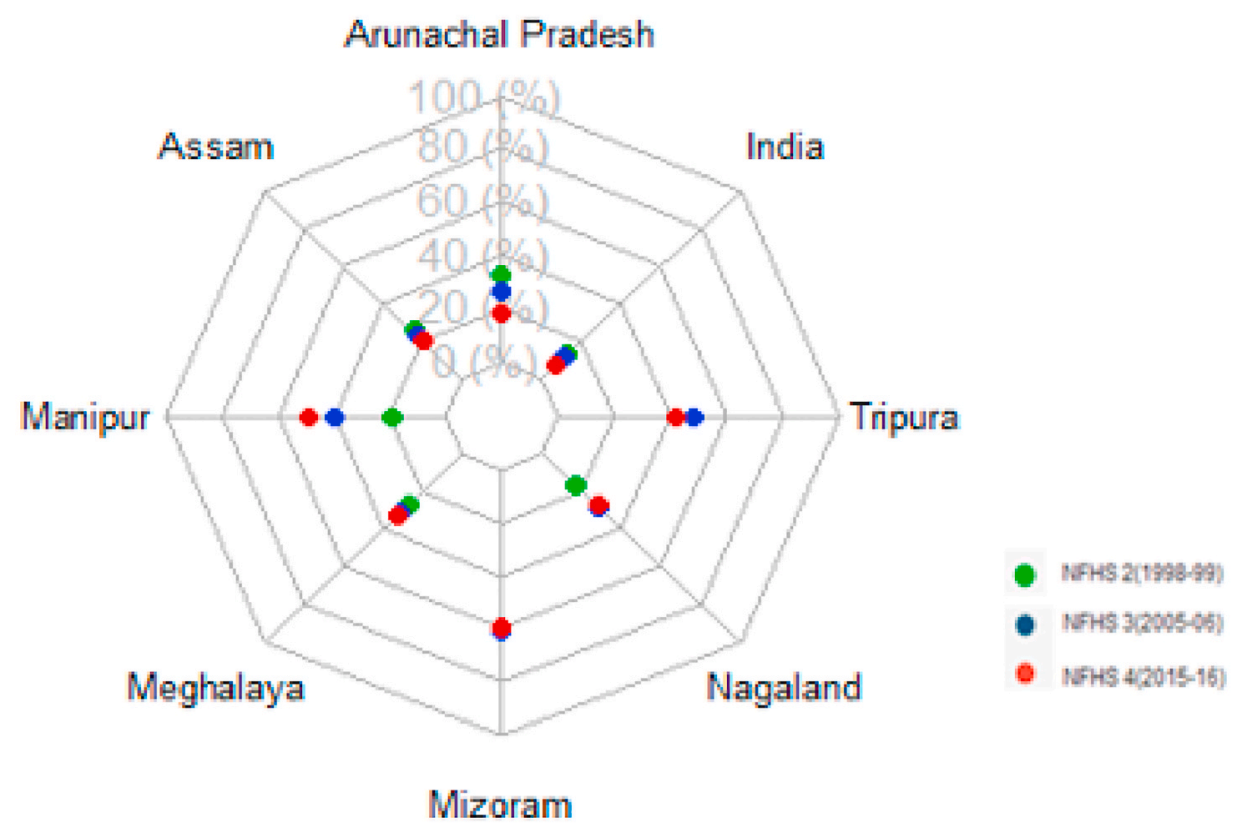

Fig. 2. Prevalence of any types of tobacco use among women in northeastern states, India.

on northeast India but shall also strengthen evidence-based public health programmes in the region, states and district level.

\section{Design, data}

This unit level data of 93,409 eligible women aged 15-49 years from a survey of representative 89,985 households from north-eastern states, India, extracted from the recent round of National Family Health Survey-4 (2015-16). NFHS-4 is the fourth in the series of National Family Health Survey in India conducted by the International Institute for Population Sciences, Mumbai and has been commissioned by the Ministry of Health \& Family Welfare, Government of India. ${ }^{10} \mathrm{~A}$ multi-stage stratified sampling design was adopted and computer assisted personal interview (CAPI) was used for collection of data from individual respondents by interviewer. The use of a multi-stage sampling design guarantees that, in the sense of the theory of probability sampling, the sample was geographically representative of the whole NE population.

\subsection{Variables description}

Outcome variable: Outcome variable is defined as current use of at least one substance of smokeless tobacco (SLT) in some form or other (gutkha/paan masala with tobacco, khaini, paan with tobacco, snuff and other chewing tobacco). This is coded as ' 1 ' for current users of smokeless tobacco and ' 0 ' otherwise.

Independent variables: Based on the theoretical and empirical importance applied in the international literature on tobacco and its availability in the dataset, a range of individual, household, community and district level explanatory variables were used for this study in order to assess their significance in determining use of SLT. Current age of women has been categorized into four broad age groups 15-19, 20-29, $30-39$ and $40-49$ years are considered. These age groups correspond to adolescents/teenagers, young, adults and older women respectively. Current marital status has been categorized into never married, currently married, and widowed/divorced/separated/deserted to assess differential in use of smokeless tobacco. Pregnancy status is categorized currently pregnant and currently not pregnant. Educational status refers to the highest educational level the woman attained and it has been categorized into four groups as 'Illiterate', 'less than 5 years', '5-9 years' and ' 10 or more year'. Number of living children has been coded as categories starting from 'No child', '1-2 child', and ' $3 \&$ more child'. Social status group classification has been used the terminology adopted by government of India which focused more on the socially disadvantaged castes/tribes; and religion i.e., 'Hindu', 'Muslim', 'Christian' and 'Others' and place of residence rural and urban. Relative socio-economic status (household wealth index) a composite score of several indicators of household possession is based on characteristics related to the socioeconomic status of a household. It is divided into five categories: 'poorest', 'poorer', 'middle', 'richer', and 'richest' where the higher score, higher the economic status of the household.

\subsection{Methods}

Bivariate analysis was used to estimate the prevalence of SLT use by background characteristics and Chi-square test was used to access the association between SLT use and selected variables. Both point estimates and robust $95 \%$ confidence intervals were given based on robust standard errors adjusting for strata and clustering at PSU. Binary logistic regression is used to estimate and assess the adjusted associations respectively of different demographic and socioeconomic characteristics. It is typically used when the dependent variable is dichotomous and the independent variables are either continuous or categorical. Odds of an event (SLT use) are the ratio of the probability that an event will occur to the probability that it will not occur. If the probability of an event occurring is $p$, the probability of the event not occurring is (1-p). Then the corresponding odds is a value given by, odds of $\{$ Event $\}=\frac{p}{1-p}$. Since logistic regression calculates the probability of an event occurring over the probability of an event not occurring, the impact of 
Table 1

Percent distribution of women by background characteristics and prevalence (\%) of smokeless tobacco use among women in northeastern states, India, 2015-16.

\begin{tabular}{|c|c|c|c|c|}
\hline & $\begin{array}{l}\text { Unweighted } \\
\text { Sample (n = } \\
93,409)\end{array}$ & $\begin{array}{l}\text { Weighted } \\
\text { Percentage } \\
{[95 \% \mathrm{CI}]}\end{array}$ & $\begin{array}{l}\text { Smokeless } \\
\text { tobacco use } \\
\text { Yes }(\%) \\
{[95 \% \mathrm{CI}]} \\
23.1 \\
{[22.1-24.1]}\end{array}$ & $\chi^{2}$ \\
\hline \multicolumn{5}{|l|}{ Age group } \\
\hline $15-19 y r$ & 15,217 & $\begin{array}{l}16.5 \\
{[16.1-16.9]}\end{array}$ & 8.6 [7.7-9.7] & $4322.52^{* * *}$ \\
\hline $20-29 y r$ & 31,459 & $\begin{array}{l}34.3 \\
{[33.8-34.8]}\end{array}$ & $\begin{array}{l}18.3 \\
{[17.2-19.4]}\end{array}$ & \\
\hline $30-39 y r$ & 26,693 & $\begin{array}{l}27.6 \\
{[27.2-28.1]}\end{array}$ & $\begin{array}{l}29.2 \\
{[27.9-30.6]}\end{array}$ & \\
\hline $40-49 y r$ & 20,040 & $\begin{array}{l}21.6 \\
{[21.2-22.0]}\end{array}$ & $\begin{array}{l}34.9 \\
{[33.3-36.5]}\end{array}$ & \\
\hline \multicolumn{5}{|l|}{ Marital status } \\
\hline $\begin{array}{l}\text { Never } \\
\text { married }\end{array}$ & 25,607 & $\begin{array}{l}24.3 \\
{[23.7-24.8]}\end{array}$ & $\begin{array}{l}11.2 \\
{[10.4-12.1]}\end{array}$ & $2725.83^{* * *}$ \\
\hline $\begin{array}{l}\text { Currently } \\
\text { married }\end{array}$ & 62,598 & $\begin{array}{l}70.5 \\
{[70.0-71.2]}\end{array}$ & $\begin{array}{l}26.5 \\
{[25.3-27.7]}\end{array}$ & \\
\hline $\begin{array}{l}\text { Widow/ } \\
\text { Divorced }\end{array}$ & 5204 & $5.2[5.0-5.4]$ & $\begin{array}{l}36.9 \\
{[34.6-39.3]}\end{array}$ & \\
\hline \multicolumn{5}{|c|}{ Pregnancy status } \\
\hline $\begin{array}{l}\text { Currently } \\
\text { not } \\
\text { pregnant }\end{array}$ & 89,014 & $\begin{array}{l}95.9 \\
{[95.6-96.1]}\end{array}$ & $\begin{array}{l}23.2 \\
{[22.2-24.2]}\end{array}$ & $9.80 *$ \\
\hline $\begin{array}{l}\text { Currently } \\
\text { pregnant }\end{array}$ & 4395 & $4.1[3.9-4.4]$ & $\begin{array}{l}21.0 \\
{[18.8-23.4]}\end{array}$ & \\
\hline \multicolumn{5}{|l|}{ Education } \\
\hline Illiterate & 17,536 & $\begin{array}{l}20.5 \\
{[19.7-21.3]}\end{array}$ & $\begin{array}{l}31.1 \\
{[29.3-33.0]}\end{array}$ & $1742.26^{* * *}$ \\
\hline $\begin{array}{l}\text { Less than } 5 \\
\text { years }\end{array}$ & 8802 & $\begin{array}{l}10.4 \\
{[10.0-10.8]}\end{array}$ & $\begin{array}{l}30.7 \\
{[28.9-32.7]}\end{array}$ & \\
\hline 5-9 years & 37,697 & $\begin{array}{l}41.0 \\
{[40.3-41.7]}\end{array}$ & $\begin{array}{l}22.5 \\
{[21.3-23.7]}\end{array}$ & \\
\hline $\begin{array}{l}10 \text { or more } \\
\text { years }\end{array}$ & 29,374 & $\begin{array}{l}28.1 \\
{[27.2-29.1]}\end{array}$ & $\begin{array}{l}16.1 \\
{[15.1-17.1]}\end{array}$ & \\
\hline \multicolumn{5}{|c|}{ No. of living children } \\
\hline No child & 31,667 & $\begin{array}{l}31.6 \\
{[31.1-32.2]}\end{array}$ & $\begin{array}{l}12.8 \\
{[12.0-13.7]}\end{array}$ & $3445.23^{* * *}$ \\
\hline 1-2_child & 15,541 & $\begin{array}{l}19.7 \\
{[19.2-20.1]}\end{array}$ & $\begin{array}{l}20.7 \\
{[19.4-22.0]}\end{array}$ & \\
\hline $\begin{array}{l}3 \& \text { more } \\
\text { child }\end{array}$ & 46,201 & $\begin{array}{l}48.7 \\
{[48.1-49.3]}\end{array}$ & $\begin{array}{l}31.2 \\
{[29.8-32.5]}\end{array}$ & \\
\hline \multicolumn{5}{|c|}{ Social status group } \\
\hline $\begin{array}{l}\text { Schedule } \\
\text { Castes }\end{array}$ & 6798 & $\begin{array}{l}10.6 \\
{[9.7-11.6]}\end{array}$ & $\begin{array}{l}27.2 \\
{[24.9-29.6]}\end{array}$ & $297.10 * * *$ \\
\hline $\begin{array}{l}\text { Schedule } \\
\text { Tribes }\end{array}$ & 52,492 & $\begin{array}{l}26.3 \\
{[24.8-27.9]}\end{array}$ & $\begin{array}{l}25.9 \\
{[24.6-27.3]}\end{array}$ & \\
\hline $\begin{array}{l}\text { Other } \\
\text { Backward } \\
\text { Classes }\end{array}$ & 12,120 & $\begin{array}{l}22.7 \\
{[21.2-24.2]}\end{array}$ & $\begin{array}{l}20.6 \\
{[19.1-22.2]}\end{array}$ & \\
\hline Others & 21,999 & $\begin{array}{l}40.4 \\
{[38.5-42.2]}\end{array}$ & $\begin{array}{l}22.1 \\
{[20.5-23.9]}\end{array}$ & \\
\hline \multicolumn{5}{|l|}{ Religion } \\
\hline Hindu & 33,681 & $\begin{array}{l}57.3 \\
{[55.3-59.3]}\end{array}$ & $\begin{array}{l}21.6 \\
{[20.5-22.8]}\end{array}$ & $564.71^{* * *}$ \\
\hline Muslim & 10,973 & $\begin{array}{l}24.7 \\
{[22.7-26.7]}\end{array}$ & $\begin{array}{l}22.2 \\
{[19.8-24.8]}\end{array}$ & \\
\hline Christian & 41,000 & $\begin{array}{l}15.4 \\
{[14.5-16.6]}\end{array}$ & $\begin{array}{l}29.8 \\
{[28.4-31.3]}\end{array}$ & \\
\hline Others & 7755 & $2.6[2.3-2.9]$ & $\begin{array}{l}32.8 \\
{[30.3-35.4]}\end{array}$ & \\
\hline \multicolumn{5}{|c|}{ Wealth index quintile } \\
\hline Poorest & 17,616 & $\begin{array}{l}17.6 \\
{[16.7-18.5]}\end{array}$ & $\begin{array}{l}26.8 \\
{[25.0-28.6]}\end{array}$ & $548.20 * * *$ \\
\hline Poorer & 18,963 & $\begin{array}{l}19.1 \\
{[18.4-19.8]}\end{array}$ & $\begin{array}{l}25.8 \\
{[24.3-27.4]}\end{array}$ & \\
\hline Middle & 19,721 & $\begin{array}{l}20.4 \\
{[19.7-21.1]}\end{array}$ & $\begin{array}{l}24.7 \\
{[23.3-26.2]}\end{array}$ & \\
\hline Richer & 19,549 & $\begin{array}{l}21.2 \\
{[20.5-22.0]}\end{array}$ & $\begin{array}{l}22.5 \\
{[21.0-24.0]}\end{array}$ & \\
\hline
\end{tabular}

Table 1 (continued)

\begin{tabular}{|c|c|c|c|c|}
\hline & $\begin{array}{l}\text { Unweighted } \\
\text { Sample (n = } \\
93,409)\end{array}$ & $\begin{array}{l}\text { Weighted } \\
\text { Percentage } \\
{[95 \% \mathrm{CI}]}\end{array}$ & $\begin{array}{l}\text { Smokeless } \\
\text { tobacco use } \\
\text { Yes (\%) } \\
{[95 \% \mathrm{CI}]} \\
23.1 \\
{[22.1-24.1]}\end{array}$ & $\chi^{2}$ \\
\hline & & $\begin{array}{l}21.7 \\
{[20.5-23.0]}\end{array}$ & $\begin{array}{l}17.8 \\
{[16.4-19.2]}\end{array}$ & \\
\hline \multicolumn{5}{|c|}{ Place of residence } \\
\hline Rural & 68,289 & $\begin{array}{l}79.7 \\
{[78.1-81.1]}\end{array}$ & $\begin{array}{l}22.7 \\
{[21.5-23.9]}\end{array}$ & $81.30 * * *$ \\
\hline Urban & 25,120 & $\begin{array}{l}20.3 \\
{[18.9-21.9]}\end{array}$ & $\begin{array}{l}25.8 \\
{[23.9-27.7]}\end{array}$ & \\
\hline \multicolumn{5}{|l|}{ State } \\
\hline $\begin{array}{l}\text { Arunachal } \\
\text { Pradesh }\end{array}$ & 14,294 & $\begin{array}{l}15.3 \\
{[15.0-15.5]}\end{array}$ & $\begin{array}{l}13.5 \\
{[12.3-14.8]}\end{array}$ & $4568.92^{* * *}$ \\
\hline Assam & 28,447 & $\begin{array}{l}30.4 \\
{[30.2-30.7]}\end{array}$ & $\begin{array}{l}18.3 \\
{[17.1-19.7]}\end{array}$ & \\
\hline Manipur & 13,593 & $\begin{array}{l}14.6 \\
{[14.3-14.8]}\end{array}$ & $\begin{array}{l}46.1 \\
{[44.7-47.4]}\end{array}$ & \\
\hline Meghalaya & 9202 & $\begin{array}{l}9.8 \\
{[9.7-10.0]}\end{array}$ & $\begin{array}{l}27.5 \\
{[25.0-30.1]}\end{array}$ & \\
\hline Mizoram & 12,279 & $\begin{array}{l}13.1 \\
{[12.9-13.4]}\end{array}$ & $\begin{array}{l}47.8 \\
{[44.5-51.1]}\end{array}$ & \\
\hline Nagaland & 10,790 & $\begin{array}{l}11.6 \\
{[11.3-11.7]}\end{array}$ & $\begin{array}{l}25.3 \\
{[23.7-27.0]}\end{array}$ & \\
\hline Tripura & 4804 & $5.1[5.0-5.3]$ & $\begin{array}{l}40.1 \\
{[37.9-42.2]}\end{array}$ & \\
\hline
\end{tabular}

Levels of significance: ${ }^{*} \mathrm{p}<0.01 ; * * \mathrm{p}<0.05 ; * * * \mathrm{p}<0.01$.

Table 2

Multicollinearity evaluation results.

\begin{tabular}{llll}
\hline Covariates & VIF & Covariates & VIF \\
\hline Age group & 1.926 & Social status group & 3.603 \\
Marital status & 3.712 & Religion & 4.043 \\
Pregnancy status & 1.483 & Wealth index quintile & 1.575 \\
Education & 1.693 & Place of residence & 1.281 \\
Number of living children & 4.093 & State & 1.334 \\
\hline
\end{tabular}

Source: Author's estimates

independent variables is usually explained in terms of odds ratio. With logistic regression, the mean of the response variable $\mathrm{p}$ in terms of an explanatory variable $\mathrm{x}$ is model relating $\mathrm{p}$ and $\mathrm{x}$ through the equation $\mathrm{p}$ $=\alpha+\beta \mathrm{x}$. Unfortunately, this is not a good model because extreme values of $\mathrm{x}$ will give values of $\alpha+\beta \mathrm{x}$ that does not fall between 0 and 1 . The logistic regression solution to this problem is to transform the odds using the natural logarithm. With logistic regression, model the natural log odds is a linear function of the explanatory variable:

$\operatorname{logit}(\mathrm{y})=\ln ($ odds $)=\ln \left(\frac{p}{1-p}\right)=a+\beta \chi$

where $\mathrm{p}$ is the probability of interested outcome that is SLT use and $\mathrm{x}$ is the explanatory variable. The parameters of the logistic regression are $\alpha$ and $\beta$.

Traditionally, the logistic regression is used to estimate Odd Ratio (OR), ${ }^{11}$ is a good estimator of Prevalence Ratio (PR) when the prevalence is low, but it is known that OR overestimates PR when the prevalence is moderate or high (e.g., prevalence rates above $10 \%)^{12}$ The PR is defined as the prevalence exposed population divided by the prevalence in non-exposed. PR, as a measure of association, is more intuitive and easier to understand than OR; and easier to interpret and communicate, especially to non-epidemiologists. ${ }^{11}$ Log-binomial regression is applied after logistic regression.

The log-binomial model results odds ratio is similar to logistic regression assuming the outcome follows binomial distribution. However, in a logistic regression the link function is the logarithm of the odds, which is the ratio between cases and non-cases, while in binomial 


\section{Prevalence of smokeless tobecoo use amoug women by district in northesatem states, India, 2015-16}

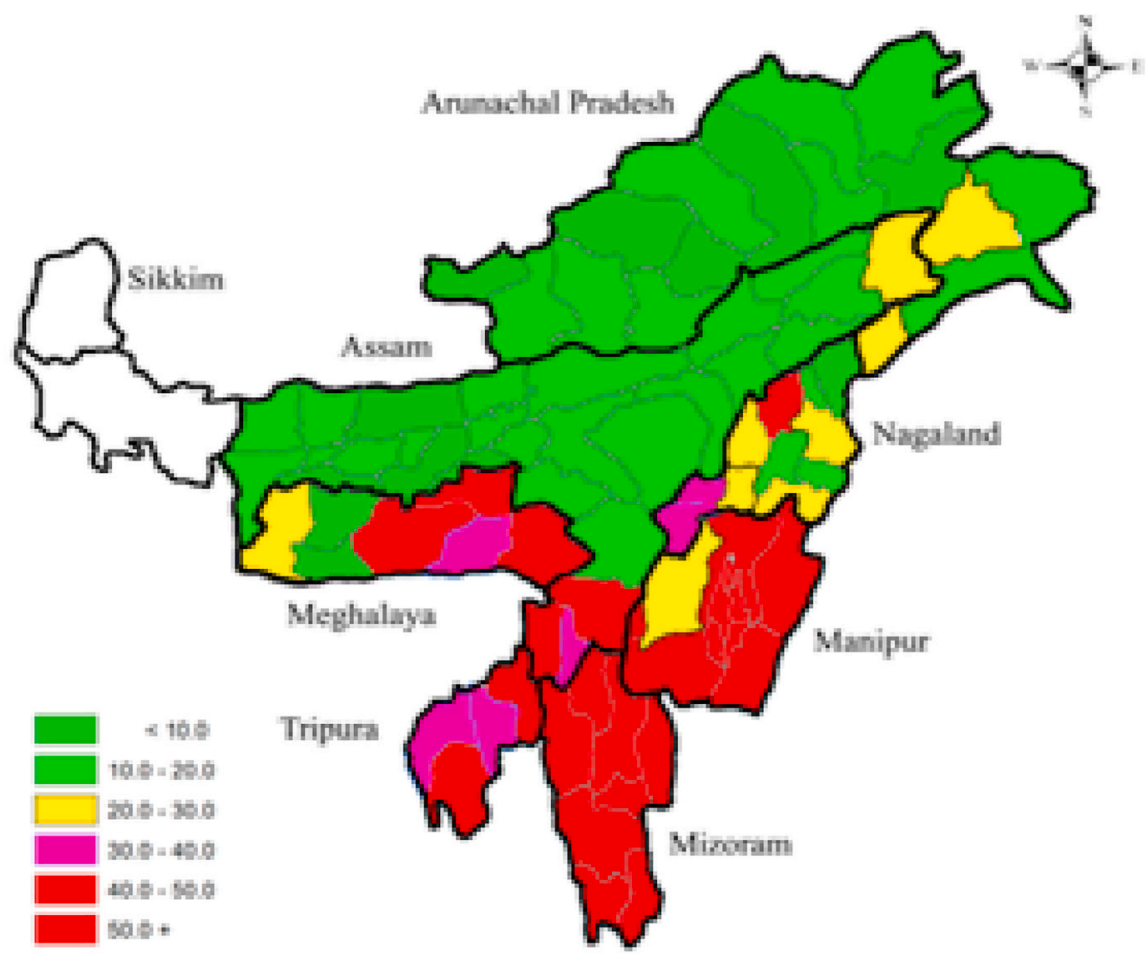

Fig. 3. Prevalence of smokeless tobacco use among women by district in northeastern states, India, 2015-16.

regression the link function is the logarithm of the proportion, i.e., the ratio between cases and cases plus non-cases. ${ }^{13}$

In a log-binomial regression model with $k$ covariates, the function is written as

$\log \left[\frac{a}{a+b}\right]=\beta_{0}+\beta_{1} X_{1}+\ldots \ldots \ldots \ldots \ldots \ldots+\beta_{k} X_{k}$

where $a$ is the number of cases and $b$ is the number of non-cases, and $X_{i}$ the covariates. Thus, $a /(a+b)$ is the probability of success (e. g., the proportion of SLT used in a group), and the PR (or RR) estimated of a given covariate $X i$ is $\varepsilon^{\beta l}$.

On the other hand, in a logistic regression model, the function is written as

$\log \left[\frac{a}{b}\right]=\beta_{0}+\beta_{1} X_{1}+\ldots \ldots \ldots \ldots \ldots \ldots \ldots+\beta_{k} X_{k}$

where $a / b$ is the odds of success and the OR estimated of a given covariate $X i$ is $\varepsilon^{\beta l}$.

One of the simplest methods to calculate PR from a given $\mathrm{OR}^{14}$ is

$P R=\frac{O R}{\left(1+p_{1}^{*}[O R-1]\right)}$

where $\mathrm{p}_{1}$ is the prevalence of the SLT use or condition in the reference group.

Overestimation of OR with respect to PR was calculated using the formula $^{15}$

Overestimation $=\frac{(O R-P R)}{(O R-1)}$

where $\mathrm{OR}$ is the odds ratio and $\mathrm{PR}$ is the prevalence ratio.

For line smoothened local polynomial smooths is applied as it has better statistical properties; it fits a local pth-order polynomial instead of fitting a local mean. Local polynomial regression is a generalization of local mean smoothing. ${ }^{16}$

\subsubsection{Spatial autocorrelation Moran's I, LISA and hot spot}

For spatial analysis, we extracted northeastern states shapefile from India shapefile after downloading through Datameet, the final feature class had 82 polygons, representing each survey district in NFHS-4, not included four districts of Sikkim. We compute global Moran's I, which gives the overall spatial autocorrelation and LISA (Local Indicator Spatial autocorrelation) a local Moran's $I$, which indicates the "presence or absence of significant spatial clusters or outliers for each location" in the dataset. Global spatial autocorrelation, Moran's I, captures the extent of overall clustering or quantify the degree of spatial autocorrelation that exists in a dataset across all the 82 districts in north-eastern states. A Moran's $I$ value near +1.0 indicates spatial clustering; 0 indicates randomness; and a value near -1.0 indicates dispersion. Local Indicator Spatial Autocorrelation, LISA, essentially measures the statistical association between the value in district $I$ and the values in nearby district; and univariate LISA statistics measures the extent of spatial nonstationery and clustering to its neighborhood values. A positive LISA statistic identifies a spatial concentration of similar values and a negative value, a spatial cluster of dissimilar values, such as an area with a high outcome's values surrounded by areas with low outcomes values. After confirmation of the presence of clustering within the dataset, hotspot analysis is further carried out using Getis-Ord $\mathrm{Gi}^{*}$ statistic, taking cluster/PSU as a feature in the dataset. ${ }^{17}$ The Hot Spot Analysis tool compute the Getis-Ord $\mathrm{Gi}^{*}$ statistic for each feature in the dataset and resultant $\mathrm{Z}$ score of $\mathrm{Gi}^{*}$ statistic tells where the features spatially clustering with either high or low values. A high z-score and a low p-value indicates a significant hotspot; and a low negative z-score and a small p-value indicates a significant cold spot. A z-score near 0 means no 


\section{Univariate LISA cluster map of amoleless toboco yse anong wowen by district in northeastem, India}

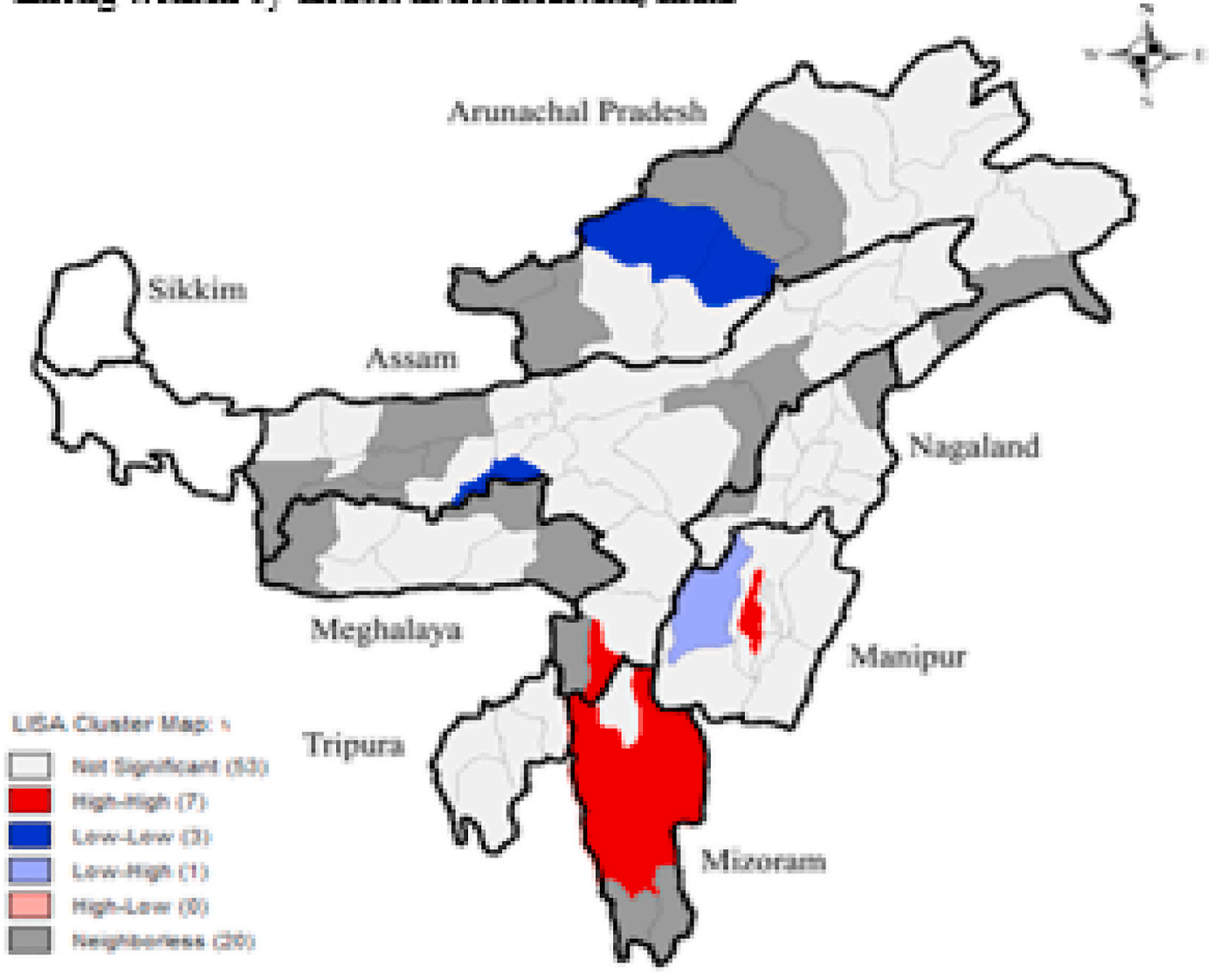

Fig. 4. Univariate LISA cluster map of smokeless tobacco use among.

spatial clustering.

Statistical analysis was performed using STATA software 13.1. Odds ratio (OR), prevalence ratio (PR) and 95\% confidence intervals (CI) were estimated using logistic regression and log-binomial regression. In order to obtain corrected CIs by log-binomial regression, the robust variance option was applied. Multicollinearity was used to investigate if the independent variables are correlated. Variables were dropped in the regression model to avoid multicollinearity and for the best fit is mentioned in below Table 2. Prior to inclusion of all the variables in multivariate analysis, multicollinearity evaluation is done using Variance Inflation Factor (VIF), that is, 1/Tolerance, which measures how much the variance of a regression coefficient is inflated due to multicollinearity in the model, since small VIF values indicates low correlation among predictor variables. Sampling weight with svy command in STATA were used to ensure the actual representativeness of the survey results. Choropleth map, spatial analysis Moran's-I and LISA were carried out using $\mathrm{R}$.

\section{Results}

Fig. 3 represents the district wise prevalence of smokeless tobacco use among women by districts in North-eastern states, India, 2015-16. The highest prevalence was observed in all the districts of Mizoram, all districts of Manipur (except Tamenglong district), Mokokchung district of Nagaland, South and North Tripura districts of Tripura, East and West Jantia Hills, Ribhoi, west and South West Khasi Hills of Meghalaya, Karimganj and Cachar district of Assam. Fig. 4 shows the Univariate LISA cluster prevalence map of smokeless tobacco use among women by districts in North-eastern states, India, 2015-16. The dark red represents high-high cluster (Imphal West district of Manipur, Hailakandi District of Assam, Lunglei, Mamit, Aizawl, champai, Serchhip districts of Mizoram), dark blue indicates low-low cluster (Kamrup district of Assam, Lower Subansiri, Kurung Kumey districts of Arunachal Pradesh), and the light blue indicates the low-high spatial outliers (Tamenglong district of Manipur). Fig. 5 shows the LISA significant cluster map of smokeless tobacco use among women by districts in Northeastern states, India, 2015-16. The very light grey represents not significant cluster (53 districts), the very light green represents significant at 0.05 level (6 district), the green represents significant at 0.01 level ( 3 districts), the dark green represents significant at 0.001 level ( 2 districts), and the dark grey represents neighbourless (20 districts). Fig. 6 shows the state level hotspot analysis smokeless tobacco use among women by districts in Northeastern states, India, 2015-16. Higher concentration of hotspots which is represented by red dots can be seen in the states of Manipur, Mizoram, Tripura and lower Assam (Karimganj and Cachar districts), Jantia Hills and Khasi Hills of Meghalaya and Mokokchung district in Nagaland. Green spot represents cold spot and almost no cold spot can be seen in Mizoram, Tripura and Manipur.

Since it is important to document the sample size for each category of the variable so that the unweighted frequency sample is reported in Table 1 . Table 1 presents the weighted percent distribution of 93,409 women, total sample, with $95 \%$ confidence interval by background characteristics and prevalence of smokeless tobacco use among women. $71 \%$ were currently married women, majority $(96 \%)$ were not pregnant, $49 \%$ women having three or more children, $57 \%$ of women were belongs to Hindu religion, $80 \%$ were living in rural area; and $10 \%$ and $5 \%$ women were representative sample women from state Meghalaya and Tripura, other states representative women were found $12-30 \%$. Prevalence of SLT use among women in north-eastern state, is also shown in Table 2, overall prevalence is $23.1 \%$. The SLT prevalence shows gradual 


\section{Uninate LISA significat mep of amokeless tobacco wa by district anong womeo in cortheast states, India}

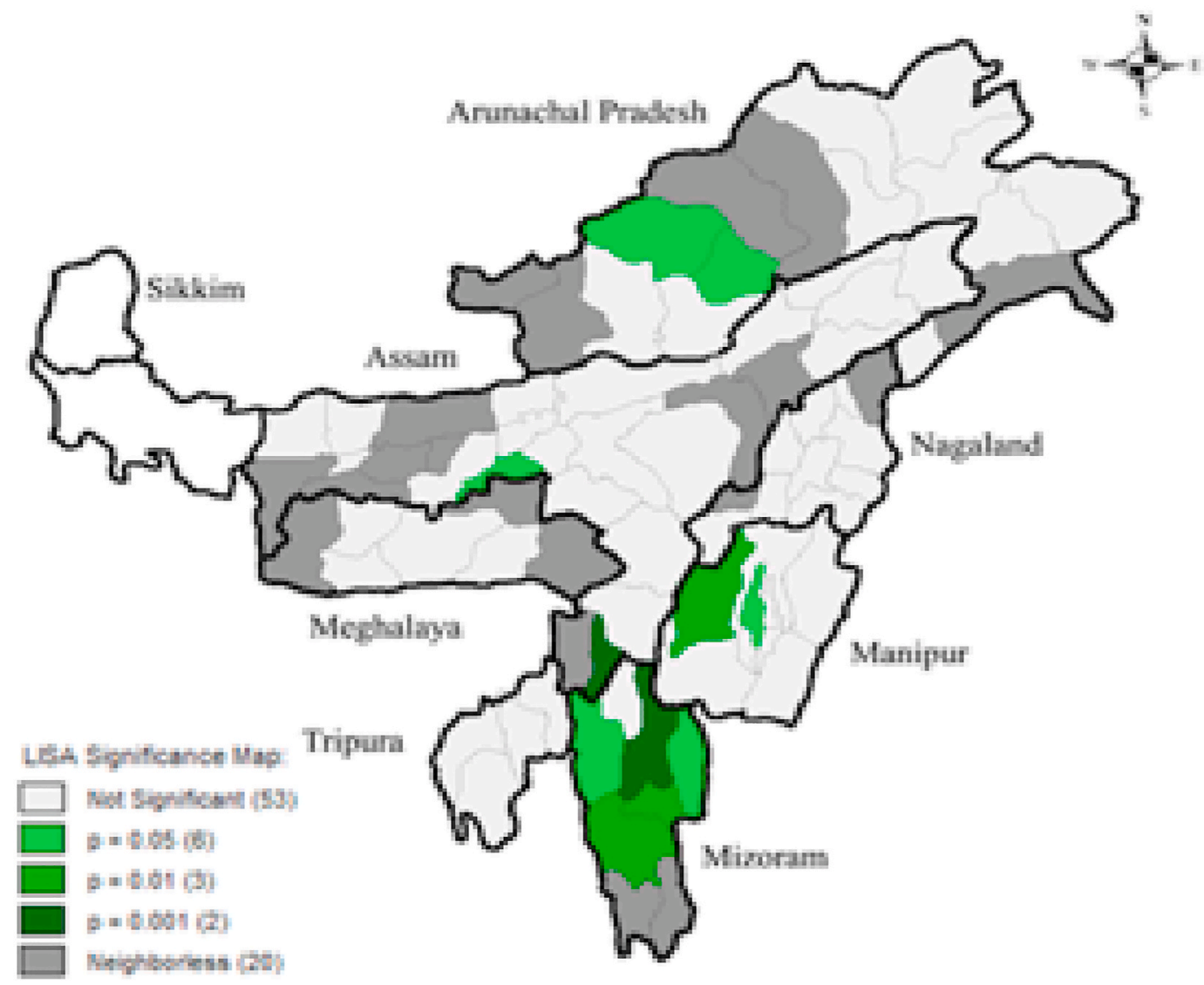

Fig. 5. LISA Significant cluster map of smokeless tobacco use among women by district in northeast states, India, 2015-16.

increase with advancement in the age group. The age group SLT prevalence were $20-29,30-39$ and $40-49,18 \%, 29 \%$ and $35 \%$ respectively, this shows that when age increased, prevalence was also increased. Prevalence among currently married women was $27 \%$ and higher prevalence was depicted $37 \%$ among widow/divorced/separated/disserted. Prevalence among currently pregnant and currently not pregnant women were shown almost same. Low level of education among women show higher level of prevalence, $31 \%$ among illiterate women and also less than 5 years schooling. Women having higher number of living children showing higher prevalence, $21 \%$ for the women having $1-2$ children and $31 \%$ for the mother having three and more children. Prevalence was slightly higher among schedule castes and schedule tribes than the other social group. Women living with lower level of household wealth index quintile showing higher prevalence of SLT use, $26 \%$ and $27 \%$ for poorer and poorest quintile, respectively. Prevalence was slightly higher among the women who were living in urban area, $(26 \%)$ than the women living in rural area (23\%). Women living in Mizoram (48\%) showing highest prevalence of SLT; followed by Manipur (46\%) and Tripura (40\%).

Fig. 3 show the choropleth map by district in north-eastern states. The red colour indicates a high prevalence and green colour shows the lower. The highest prevalence was observed in all district of Mizoram ( $40 \%$ and above), all district of Manipur ( $40 \%$ and above) except Tamenglong district; four districts of Meghalaya, namely, West Khasi Hills, East Khasi Hills, Ri-Bhoi and Jaintia Hills; Cachar, Hailakandi and Karimganj districts of Assam; and Mokokochung, Peren and Dimapur district of Nagaland. Moran's I value for the prevalence of SLT use is $0.5776(\mathrm{p}<0.001)$ which is a positive autocorrelation and indicates that there is spatial clustering between the neighbouring districts. Fig. 4 shows the univariate LISA cluster prevalence map, the dark red colour represents high-high cluster (7 district), dark blue indicates the low-low clusters ( 3 district), light blue indicates the low-high spatial outliers (1 district), and light red represent the high-low spatial outliers, but no high-low district. Univariate LISA significance map (Fig. 5) shows the locations with a significant local statistic, with the degree of significance reflected in increasingly darker shades of green. There are 6 districts with $\mathrm{p}=0.05$ significant level, 3 districts with $\mathrm{p}=0.01$, and 2 districts with $\mathrm{p}=0.001$ in the significance map.

Cluster-wise prevalence of SLT use was done, figure not shown, thereafter, Getis-Ord Gi* statistic was applied for hotspots analysis, in total 4032 clusters were used in the analysis, where 949 clusters showed as hotspot, 1488 clusters as cold spot and 1595 cluster found as not significant. Fig. 6 depicts the hotspot and cold spot, and result reveals that all most all cluster in Mizoram were found as hotspot; hotspot cluster were portray in West Tripura district and North Tripura district; in Meghalaya, East Khasi Hills, Ri-Bhoi, Jaintia Hills and West Khasi Hills districts; in Assam, Hailakandi, Karimganj and Cachar district; in Manipur, Imphal East, Imphal West, Thoubal, Bishnupur district and also some part in Ukhrul, Senapati, Chandel and Churchandpur district; and in Nagaland, hotspot cluster were shown only in Mokokchung district.

Fig. 7 depicts that state wise prevalence of SLT among women, Mizoram $(47.8 \pm 1.2)$ showing highest in NE states, and followed by Manipur $(46.1 \pm 0.7)$. Fig. 8 showed the fitted 2nd order local polynomial smoothened graph, it depicts the prevalence of SLT use among women is drastically increasing when women age is increasing, then 


\section{Hotspots of prevalence of emokeless tobacco use mong wowen in northesst atates, India}

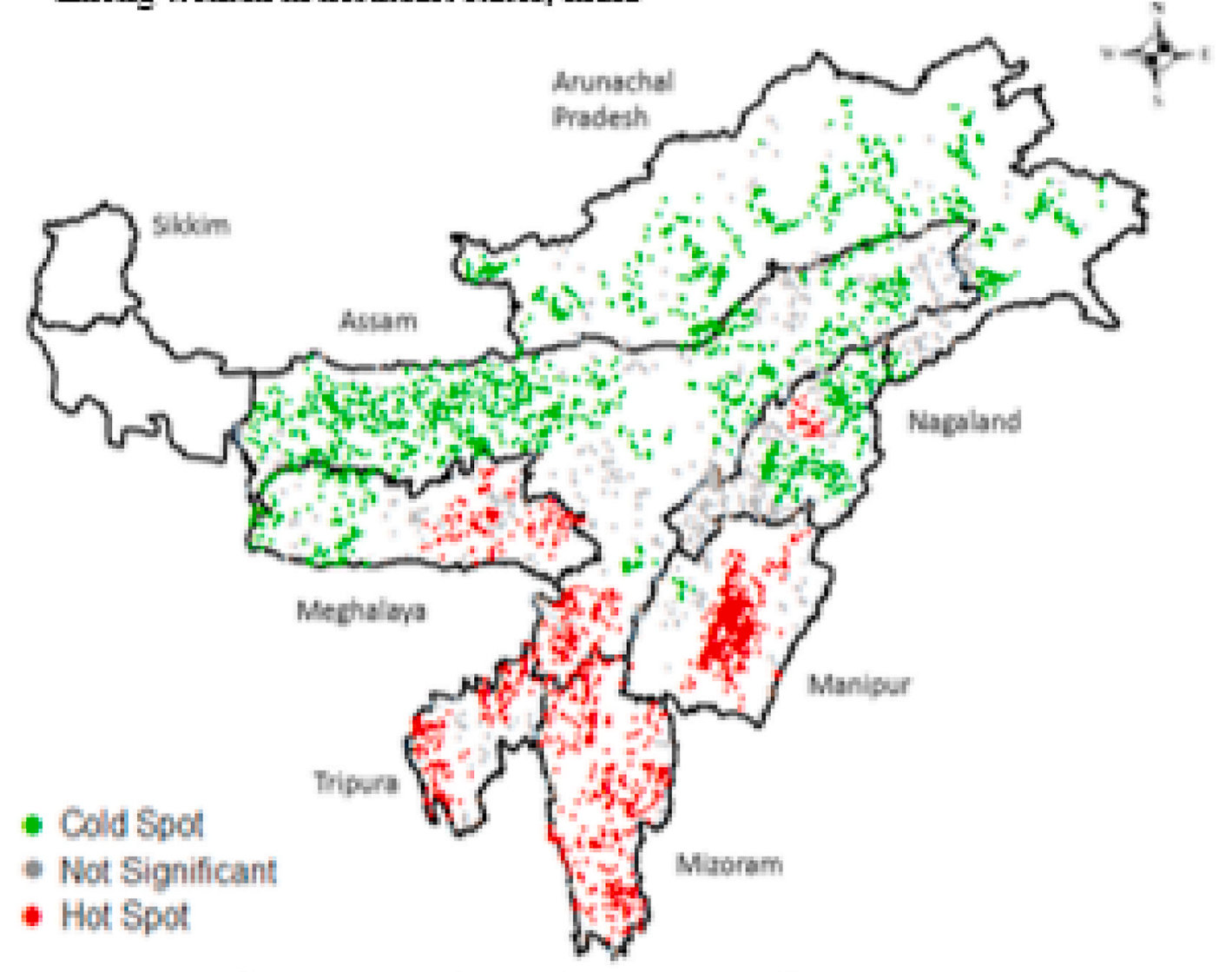

Fig. 6. Hotspot and cold spat of prevalence of smokeless tobacco use among women in northeast states, India, 2015-16.

from age 41 till age 49 showing prevalence is flattening.

\subsection{Multicollinearity analysis}

Table 2 shows the results of the multicollinearity analysis. The VIF (Variance Inflation Factor) values of all variables were less than 5, so it could be considered that there was no multicollinearity among the explanatory variables, and all variables were included in logistic and log-binomial regression analysis.

Table 3 presents the crude odds ratio, adjusted odds ratio and prevalence ratio of SLT use among women estimated using binary logistic and log-binomial regression; and overestimation of odds ratio with respect to prevalence ratio. The results of logistic regression and logbinomial, were presented in the form of estimated odds-ratio and prevalence ratio with $95 \% \mathrm{CI}$. The binary logistic regression analysis of association between background characteristics and SLT use among women indicate that use of SLT were respectively 1.9 times, 3.0 times and 3.6 times higher among women age group $20-29(\mathrm{OR}=1.91)$, $30-39(\mathrm{OR}=3.03)$ and $40-49(\mathrm{OR}=3.75)$ as compared to the women 15-19-year age group. The odds of using SLT among currently married women and window/divorced/separated/deserted women were $35 \%$ $(\mathrm{OR}=1.35)$ and $70 \%(\mathrm{OR}=1.71)$ higher as compared to never married women, after controlling other variables.

Women in the poorest, poorer and middle household wealth index having higher odds ratio than women in richest household wealth index, $1.74,1.76$ and 1.70. Odds of using SLT among the women who are living in urban areas was 1.6 times than women living in rural areas, OR = 1.58. Odds of using SLT among women living Mizoram, Manipur and Tripura were 7.9 times, 6.7 times and 4.5 times higher than women living in Arunachal Pradesh, i.e., 7.92, 6.68 and 4.54.

Results of log binomial regression shows that prevalence of SLT use among women were respectively 1.8 times, 2.6 times and 3.0 times higher among the women age group 20-29 (PR $=1.82), 30-39(\mathrm{PR}=$ $2.58)$ and $40-49(\mathrm{PR}=2.96)$ as compared to the women 15-19-year age group. Overestimation of odds ratio with respect to prevalence ratio were $10 \%, 22 \%$ and $29 \%$. Likelihood of using SLT among widow/ divorced/separated/disserted and currently married were 50\% (PR = $1.45)$ and $20 \%(P R=1.22)$ more likely compared to never married, respectively. $37 \%$ shows as overestimation of odds ratio for currently married and also widow/divorced/separated/disserted women group with respect to prevalence ratio. Women who are in household with middle quintile, poorer quintile and poorest quintile shows 1.3 times higher prevalence of SLT use than richest quintile. Odds ratio in middle, poorer and poorest quintile were found more than $60 \%$ overestimation with respect to prevalence ratio. The prevalence of SLT use was 1.21 times higher among women who living in urban area than the women living in rural area ( $P R=1.21)$. $64 \%$ was found as overestimation of odds ratio with respect to prevalence ratio. Women who are living in Mizoram, Manipur and Tripura were 6 times, 5 times and 3 times more likely to use SLT than women living in Arunachal Pradesh, prevalence ratio were $6.38,5.01$ and 2.96 respectively. Overestimation of odds ratio with respect to prevalence ratio were $45 \%$ in Tripura, $43 \%$ in Meghalaya and $31 \%$ in Manipur. All prevalence ratios were reported after controlling other variables. Lower AIC value indicates better fit relative to the model fit with a higher AIC. AIC value of the logistic regression model is 647.896 and log-binomial regression is 497.857. Log-binomial regression is a more parsimonious model than logistic regression for this dataset. 


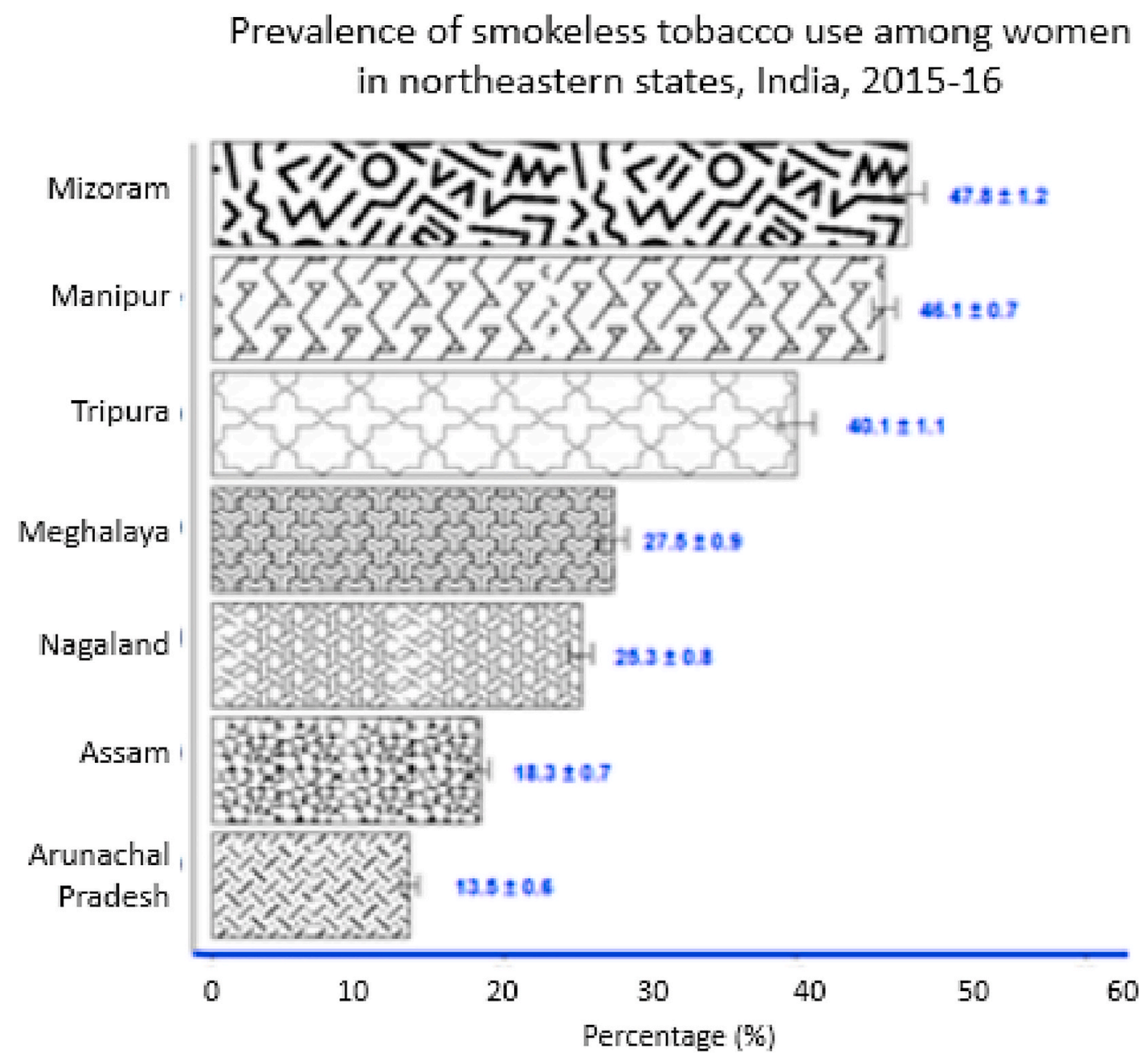

Fig. 7. Prevalence of smokeless tobacco use among women in northeastern states, India, 2015-16.

\section{Discussion}

A study on spatial analysis has shown that clustering of tobacco use among females was also predominant in North-eastern states such as Assam, Manipur, Tripura and Meghalaya. ${ }^{18}$ Another recent study also identified some districts of the North-eastern states of India (except Sikkim) as major tobacco hot spots. ${ }^{19}$ Hence, the region of North east India can be considered a high priority area in terms of tobacco use. The present study reported that prevalence of SLT use was higher in higher age group, 40-49 yrs and three times more likely to use SLT compared to the younger age group (15-19 yrs). Similar finding was reported in previous studies. ${ }^{20,21}$ Other studies have also concluded that the prevalence of SLT among women increased with the rise in age. ${ }^{22-24}$ This highlights the need to have an in-depth understanding of why women in advancing age groups are more prone to use SLT in northeastern states. Exclusive studies on women of higher age groups should be conducted to explore the unique behavioural, economic and social factors as well as the interplay of such factors leading to SLT use. The prevalence of SLT use is higher among divorced and widowed women than among currently married women and never married. Women might have initiated to SLT use directly or indirectly by peer influence for their initiation of tobacco use reported or consumption habit learned from the cultural and societal norms. Since the prevalence is found to be higher among divorced/widowed women, there may be a possibility that the use of SLT is associated with emotional/psychological distress to relieve stress among these women. It was observed that SLT use was highest among women with low-educational status and statistical association between SLT use and level of women's education was found to be statistically significant. Women with low level of education shows higher chance of probability of SLT use than educated women, result is consistent with observations that those with lower level of education are more likely to consume smokeless tobacco. ${ }^{20,21}$ This reinforces the need to focus tobacco control programs, health risks and others messages particularly to the women having low education level. The results of multivariate analysis carried out among Indian women has shown that illiterate, separated/divorced and women who are labourers/housewives are significantly associated with SLT use. ${ }^{24}$ Another cross-sectional study in India has also reported that SLT use among women is associated with illiteracy, marital status, low monthly income and occupational status. ${ }^{25}$

The prevalence is higher among the women having three or more children than the other women having less than two children and no children. Prevalence of SLT use was slightly higher among social status belongs to schedule castes and schedule tribes than the other social group. The prevalence of SLT use were highest in Christian and others religion. This might be due to the fact that most participants were belonged to Christianity and others religion. Religion was found to be significantly associated with SLT use and probability of using SLT was higher among women belongs to Christian and others religion. Any types of tobacco use in northeast region is consistently high in NFHS-4, these study results strongly affirm that SLT use is socially acceptable and integral part of the culture of the region, similar findings also reported. ${ }^{25}$ Similarly, NFHS-4 report ${ }^{9}$ showed that there is continual decrease in SLT use with increasing wealth quintiles, this study reveals that women from 


\section{Prevalence of smokeless tobacco use among women by age in northeastern states, India, 2015-16}

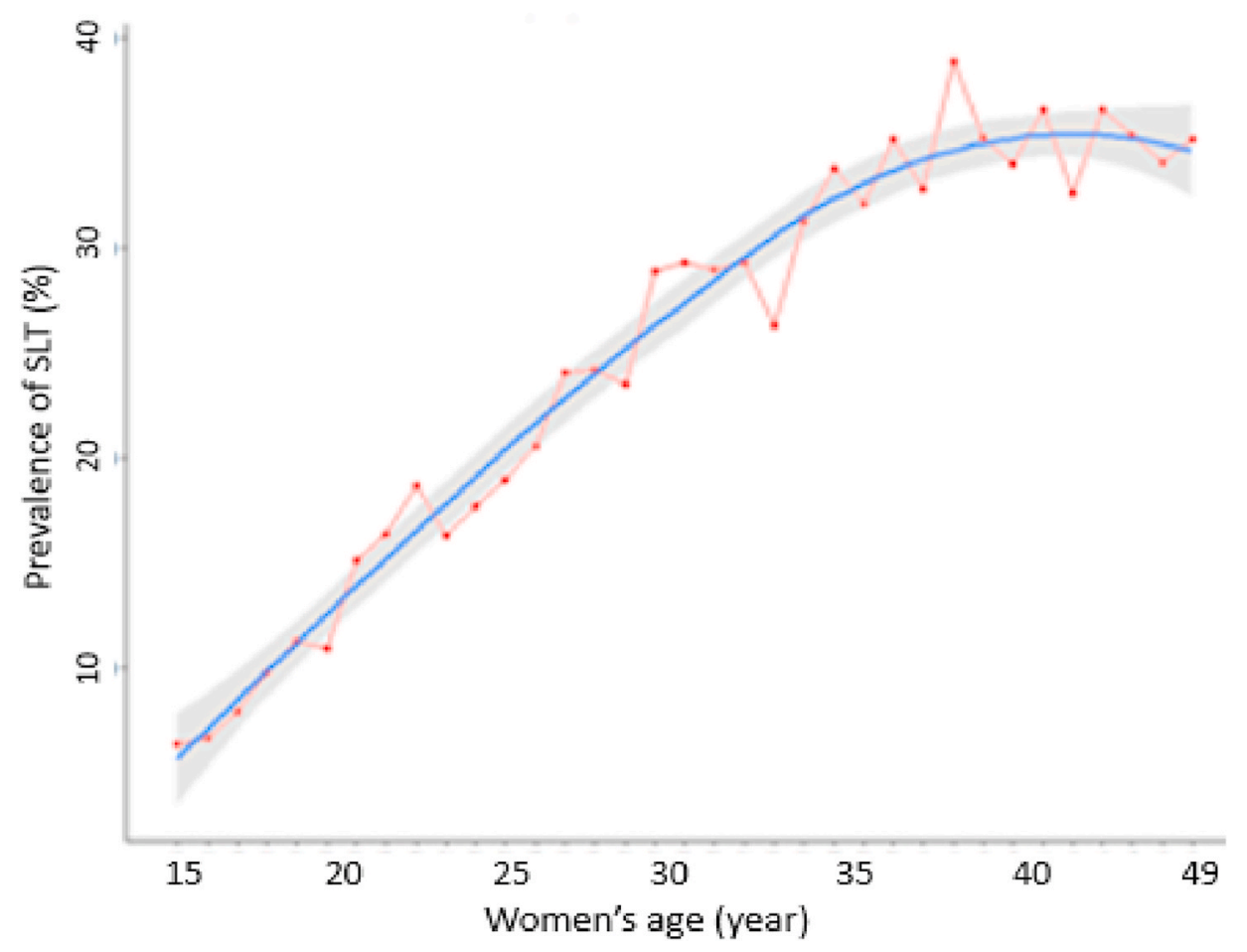

Fig. 8. Prevalence of smokeless tobacco use among women by age, northeastern states, India.

wealthy households as measured by wealth quintile have a lower risk of SLT use as compared to their peers in lower wealth quintile, finding is consistent. ${ }^{25}$ Prevalence of SLT use was slightly higher among the women who were living in urban area than the women living in rural area. Women living in urban area have a significant difference in risk of SLT use with compared to rural women. These results indicate that women facing additional burdens in life are somewhat more prone to use SLT; understanding the same from a research point of view becomes important. Policies and programs should work on specifically targeting these women who may be facing additional life challenges and difficulties as compared to their more advantaged counterparts. ${ }^{26}$

The result of spatial analysis clearly shows a pictographic evidence of the prevalence of tobacco use among women in the north-eastern Indian states. Mizoram, Manipur and Tripura as well as Lower Assam and Khasi Jantia Hills has higher concentration of users as compared to other states of North Eastern India and can be seen from the result of the analysis. Considering the results of the analysis it would be suggestible to implement programs and policies to slow down or reduce the number of hotspots in the highly affected states and their districts. Intervention and counselling specially of growing up adolescents and young adults maybe an effective strategy to counter and bring down the numbers. From the aforementioned points, the present study concludes that the use of SLT is more common among women belonging to disadvantaged groups i.e. divorced/widowed women, women with low level of education, women having more children, women belonging to lower social status group and women with low wealth quintile and suggest for targeting policies and programs on this vulnerable section of the community for stopping the use of smokeless tobacco.

\section{Strength and limitations}

It is paramount to strengthen existing tobacco control policies and cessation programme at regional and district level. The graphical depiction using spatial analysis of different findings like prevalence in states with reference to time, district-wise prevalence, high concentration of user at district level becomes convenient and extra informative as compared to conventional diagrammatic presentation. The findings suggest that health policymakers, public health professionals, the government and other voluntary organisations need to strengthen National Tobacco Control Programmes under the National Health Mission. The prevalence of SLT use among women remains a critical component of public health and concerted efforts are required to improve women health in this region. The study has a number of limitations, first, it was not possible to analysed and not adjusted for other variables like, history of SLT use, number of consumptions in a day, age of initiation time of first use in the day, daily expenditure, products consumed on daily basis, reasons for failure in attempt, number of household member use etc., due to the lack of information in the dataset. Second, the findings are based on self-reports and may have suffered response bias and underreporting.

\section{Conclusion}

The variations in SLT prevalence within the state shows there is a need for state-specific, evidence-based intervention plans, particularly in hot spot areas/clusters. All states in NE region should be directed to fully implement the National Tobacco Control Programme (NTCP) in all districts under the National Health Mission and states which have higher prevalence and have shown insufficient reduction in prevalence rates between the two survey rounds, NFHS 3 (2005-06) and NFHS 4 (2015-16) and GATS 1 (2009-10) and GATS 2 (2016-17), should give greater attention and greater technical support to implement the National Tobacco Control Programme more effectively. Tobacco cessation support needs to be strengthened, especially in the high SLT burden district as tobacco use is culturally accepted behaviour and practices in the region, therefore, the policy needs to address it from this perspective. All smokeless tobacco users who are willing to quit should be provided with necessary support interventions at cessation centres and 
Table 3

Unadjusted, adjusted odds ratio, adjusted prevalence ratio with 95\% C.I. and overestimation of odds ratio with respect to prevalence ratio estimates of smokeless tobacco use among women in northeastern states, India, 2015-16.

\begin{tabular}{|c|c|c|c|c|}
\hline & $\begin{array}{l}\text { Crude odds } \\
\text { ratio }\end{array}$ & $\begin{array}{l}\text { Adjusted } \\
\text { odds ratio } \\
\text { logistic } \\
\text { regression }\end{array}$ & $\begin{array}{l}\text { Adjusted } \\
\text { prevalence } \\
\text { ratio } \\
\text { log-binomial }\end{array}$ & $\begin{array}{l}\text { Over } \\
\text { estimation }^{\mathrm{a}}\end{array}$ \\
\hline \multicolumn{5}{|l|}{ Age group } \\
\hline $15-19 y r$ & reference & reference & reference & - \\
\hline $20-29 y r$ & $\begin{array}{l}2.50 \\
{[2.36-2.63]}\end{array}$ & $\begin{array}{l}1.91 \\
{[1.68-2.18]}\end{array}$ & $\begin{array}{l}1.82 \\
{[1.61-2.02]}\end{array}$ & $10 \%$ \\
\hline $30-39 y r$ & $\begin{array}{l}3.86 \\
{[3.65-4.07]}\end{array}$ & $\begin{array}{l}3.03 \\
{[2.61-3.47]}\end{array}$ & $\begin{array}{l}2.58 \\
{[2.27-2.93]}\end{array}$ & $22 \%$ \\
\hline $40-49 y r$ & $\begin{array}{l}4.13 \\
{[3.91-4.37]}\end{array}$ & $\begin{array}{l}3.75 \\
{[3.24-4.34]}\end{array}$ & $\begin{array}{l}2.96 \\
{[2.59-3.39]}\end{array}$ & $29 \%$ \\
\hline \multicolumn{5}{|l|}{ Marital status } \\
\hline $\begin{array}{l}\text { Never } \\
\text { married }\end{array}$ & reference & reference & reference & - \\
\hline $\begin{array}{l}\text { Currently } \\
\text { married }\end{array}$ & $\begin{array}{l}1.93 \\
{[1.83-2.01]}\end{array}$ & $\begin{array}{l}1.35 \\
{[1.27-1.53]}\end{array}$ & $\begin{array}{l}1.22 \\
{[1.10-1.35]}\end{array}$ & $37 \%$ \\
\hline $\begin{array}{l}\text { Widow/ } \\
\text { Divorced }\end{array}$ & $\begin{array}{l}3.32 \\
{[3.21-3.53]}\end{array}$ & $\begin{array}{l}1.71 \\
{[1.47-1.98]}\end{array}$ & $\begin{array}{l}1.45 \\
{[1.29-1.62]}\end{array}$ & $37 \%$ \\
\hline \multicolumn{5}{|l|}{ Pregnancy Status } \\
\hline $\begin{array}{l}\text { Currently not } \\
\text { pregnant } \\
\text { Currently } \\
\text { pregnant }\end{array}$ & $\begin{array}{l}1.13 \\
{[1.00-1.28]} \\
\text { reference }\end{array}$ & $\begin{array}{l}0.96 \\
{[0.85-1.10]} \\
\text { reference }\end{array}$ & $\begin{array}{l}0.97 \\
{[0.89-1.06]} \\
\text { reference }\end{array}$ & $25 \%$ \\
\hline \multicolumn{5}{|l|}{ Education } \\
\hline Illiterate & $\begin{array}{l}1.48 \\
{[1.23-1.56]}\end{array}$ & $\begin{array}{l}1.39 \\
{[1.25-1.55]}\end{array}$ & $\begin{array}{l}1.22 \\
{[1.13-1.31]}\end{array}$ & $44 \%$ \\
\hline $\begin{array}{l}\text { Less than } 5 \\
\text { years }\end{array}$ & $\begin{array}{l}1.63 \\
{[1.55-1.72]}\end{array}$ & $\begin{array}{l}1.55 \\
{[1.40-1.72]}\end{array}$ & $\begin{array}{l}1.34 \\
{[1.24-1.44]}\end{array}$ & $38 \%$ \\
\hline $5-9$ years & $\begin{array}{l}1.42 \\
{[1.28-1.56]}\end{array}$ & $\begin{array}{l}1.37 \\
{[1.27-1.48]}\end{array}$ & $\begin{array}{l}1.24 \\
{[1.17-1.31]}\end{array}$ & $35 \%$ \\
\hline $\begin{array}{l}10 \text { or more } \\
\text { years }\end{array}$ & reference & reference & reference & - \\
\hline \multicolumn{5}{|c|}{ No. of living children } \\
\hline No child & reference & reference & reference & - \\
\hline 1-2_child & $\begin{array}{l}1.53 \\
{[1.47-1.60]}\end{array}$ & $\begin{array}{l}1.05 \\
{[0.94-1.17]}\end{array}$ & $\begin{array}{l}1.04 \\
{[0.95-1.13]}\end{array}$ & $20 \%$ \\
\hline $\begin{array}{l}3 \& \text { more } \\
\text { child }\end{array}$ & $\begin{array}{l}2.12 \\
{[2.14-2.29]}\end{array}$ & $\begin{array}{l}1.24 \\
{[1.12-1.38]}\end{array}$ & $\begin{array}{l}1.17 \\
{[1.08-1.27]}\end{array}$ & $29 \%$ \\
\hline \multicolumn{5}{|l|}{ Social status } \\
\hline $\begin{array}{l}\text { Schedule } \\
\text { Castes }\end{array}$ & $\begin{array}{l}1.17 \\
{[1.01-1.23]}\end{array}$ & $\begin{array}{l}1.32 \\
{[1.10-1.46]}\end{array}$ & $\begin{array}{l}1.02 \\
{[0.91-1.34]}\end{array}$ & $75 \%$ \\
\hline $\begin{array}{l}\text { Schedule } \\
\text { Tribes }\end{array}$ & $\begin{array}{l}1.23[1 / \\
09-1.28]\end{array}$ & $\begin{array}{l}1.13 \\
{[0.79-1.19]}\end{array}$ & $\begin{array}{l}1.06 \\
{[0.87-1.26]}\end{array}$ & $54 \%$ \\
\hline Other & 0.90 & 0.92 & 0.94 & $25 \%$ \\
\hline $\begin{array}{l}\text { Backward } \\
\text { Classes }\end{array}$ & [0.85-1.08] & [0.81-1.04] & [0.82-1.04] & \\
\hline Others & reference & reference & reference & - \\
\hline \multicolumn{5}{|l|}{ Religion } \\
\hline Hindu & reference & reference & reference & - \\
\hline Muslim & $\begin{array}{l}1.01 \\
{[0.95-1.05]}\end{array}$ & $\begin{array}{l}0.98 \\
{[0.82-1.17]}\end{array}$ & $\begin{array}{l}0.99 \\
{[0.83-1.15]}\end{array}$ & $50 \%$ \\
\hline Christian & $\begin{array}{l}1.96 \\
{[1.41-2.05]}\end{array}$ & $\begin{array}{l}1.70 \\
{[1.48-1.94]}\end{array}$ & $\begin{array}{l}1.37 \\
{[1.28-1.48]}\end{array}$ & $47 \%$ \\
\hline Others & $\begin{array}{l}1.97 \\
{[0.92-2.03]}\end{array}$ & $\begin{array}{l}1.89 \\
{[1.62-2.20]}\end{array}$ & $\begin{array}{l}1.51 \\
{[1.38-1.66]}\end{array}$ & $43 \%$ \\
\hline \multicolumn{5}{|c|}{ Wealth index quintile } \\
\hline Poorest & $\begin{array}{l}1.94 \\
{[1.34-2.08]}\end{array}$ & $\begin{array}{l}1.74 \\
{[1.51-2.01]}\end{array}$ & $\begin{array}{l}1.29 \\
{[1.17-1.43]}\end{array}$ & $61 \%$ \\
\hline Poorer & $\begin{array}{l}1.87 \\
{[1.38-2.05]}\end{array}$ & $\begin{array}{l}1.76 \\
{[1.55-2.00]}\end{array}$ & $\begin{array}{l}1.31 \\
{[1.18-1.42]}\end{array}$ & $59 \%$ \\
\hline Middle & $\begin{array}{l}1.84 \\
{[1.35-1.98]}\end{array}$ & $\begin{array}{l}1.70 \\
{[1.51-1.92]}\end{array}$ & $\begin{array}{l}1.28 \\
{[1.17-1.40]}\end{array}$ & $60 \%$ \\
\hline Richer & $\begin{array}{l}1.28 \\
{[1.22-1.34]}\end{array}$ & $\begin{array}{l}1.27 \\
{[1.12-1.43]}\end{array}$ & $\begin{array}{l}1.19 \\
{[1.11-1.30]}\end{array}$ & $30 \%$ \\
\hline Richest & reference & reference & reference & - \\
\hline \multicolumn{5}{|c|}{ Place of residence } \\
\hline Rural & reference & reference & reference & - \\
\hline Urban & $\begin{array}{l}1.61 \\
{[1.47-1.76]}\end{array}$ & $\begin{array}{l}1.58 \\
{[1.38-1.80]}\end{array}$ & $\begin{array}{l}1.21 \\
{[1.01-1.27]}\end{array}$ & $64 \%$ \\
\hline \multicolumn{5}{|l|}{ State } \\
\hline $\begin{array}{l}\text { Arunachal } \\
\text { Pradesh }\end{array}$ & reference & reference & reference & - \\
\hline
\end{tabular}

Table 3 (continued)

\begin{tabular}{|c|c|c|c|c|}
\hline & $\begin{array}{l}\text { Crude odds } \\
\text { ratio }\end{array}$ & $\begin{array}{l}\text { Adjusted } \\
\text { odds ratio } \\
\text { logistic } \\
\text { regression }\end{array}$ & $\begin{array}{l}\text { Adjusted } \\
\text { prevalence } \\
\text { ratio } \\
\text { log-binomial }\end{array}$ & $\begin{array}{l}\text { Over } \\
\text { estimation }\end{array}$ \\
\hline Assam & $\begin{array}{l}1.44 \\
{[1.25-1.65]}\end{array}$ & $\begin{array}{l}1.40 \\
{[1.15-1.63]}\end{array}$ & $\begin{array}{l}1.33 \\
{[1.23-1.43]}\end{array}$ & $18 \%$ \\
\hline Manipur & $\begin{array}{l}5.48 \\
{[4.85-6.18]}\end{array}$ & $\begin{array}{l}6.68 \\
{[5.76-7.73]}\end{array}$ & $\begin{array}{l}5.01 \\
{[4.77-5.25]}\end{array}$ & $29 \%$ \\
\hline Meghalaya & $\begin{array}{l}2.43 \\
{[2.06-2.87]}\end{array}$ & $\begin{array}{l}2.96 \\
{[2.45-3.58]}\end{array}$ & $\begin{array}{l}2.11 \\
{[1.95-2.27]}\end{array}$ & $43 \%$ \\
\hline Mizoram & $\begin{array}{l}5.87 \\
{[4.95-6.97]}\end{array}$ & $\begin{array}{l}7.92 \\
{[6.46-9.71]}\end{array}$ & $\begin{array}{l}6.38 \\
{[6.08-6.68]}\end{array}$ & $22 \%$ \\
\hline Nagaland & $\begin{array}{l}2.18 \\
{[1.89-2.50]}\end{array}$ & $\begin{array}{l}2.53 \\
{[2.13-3.00]}\end{array}$ & $\begin{array}{l}2.12 \\
{[1.99-2.23]}\end{array}$ & $27 \%$ \\
\hline Tripura & $\begin{array}{l}4.28 \\
{[3.72-4.92]}\end{array}$ & $\begin{array}{l}4.54 \\
{[3.82-5.39]}\end{array}$ & $\begin{array}{l}2.96 \\
{[2.82-3.10]}\end{array}$ & $45 \%$ \\
\hline
\end{tabular}

(Brotman, 2006; Espelt et al., 2013; Shishehbor, Litaker, Lauer, 2006).

a Overestimation of OR with respect to PR was calculated using the formula: [Overestimation $=(\mathrm{OR}-\mathrm{PR}) /(\mathrm{OR}-1)]$.

community level. Targeting interventions toward SLT use among women should reach more effectively and counselling against SLT use should be incorporated in women's routine prenatal and antenatal health care services in this region. Accredited Social Health Activists (ASHA) and community health workers need to be trained in context of tobacco control programme to advocate SLT cessation strategies in their local community.

\section{Funding}

This research did not received any specific grand from funding agencies in the public, commercial, or not-for-profit sectors.

\section{Ethical statement}

The NFHS-4 data is available for public use in [https://dhsprogram. $\mathrm{com} /$ data/dataset.India_Standard-DHS_2015.cfm?flag=1]. Therefore, ethical statement is not required for the study.

\section{Declaration of competing interest}

No potential conflict of interest relevant to this article was reported.

\section{Acknowledgment}

We would also like to acknowledged Dr. Harpreet Kaur, Scientist-F, Division of Epidemiology and Communicable Disease, ICMR-New Delhi for her contribution in the revision and flow of the manuscript.

\section{References}

1 Report on smokeless tobacco products essential facts. https://www.tobaccofreekids. org/assets/global/pdfs/en/Smokeless_Essential_Facts_en.pdf [accessed on 3 January 2020], report.

2 WHO report on global tobacco use trends. https://www.who.int/news-room/detail 19-12-2019-who-launches-new-report-on-global-tobacco-use-trends [accessed on 23 Feb 2020], report.

3 World Health Organization. Smokeless Tobacco and Some Tobacco-Specific NNitrosamines. IARC Monographs on the Evaluation of Carcinogenic Risks to Humans. vol. 89. Lyon (France): World Health Organization, International Agency for Research on Cancer; 2007 [accessed 2018 Oct 31].

4 U.S. Department of Health and Human Services. The Health Consequences of Smoking - 50 Years of Progress: A Report of the Surgeon General. Atlanta: U.S. Department of Health and Human Services, Centers for Disease Control and Prevention, National Center for Chronic Disease Prevention and Health Promotion, Office on Smoking and Health; 2014. accessed 2018 Oct 31].

5 Understanding the oral cancer and tobacco forms and types. The Oral Cancer Foundation. https://oralcancerfoundation.org/understanding/tobacco/tobacco-for ms-types/. [accessed on $24 \mathrm{Feb}, 2019$ ].

6 Government of India (GOI). The Cigarettes and Other Tobacco Products (Prohibition of Advertisement and Regulation of Trade and Commerce, Production, Supply and 
Distribution) Act, 2003; an Act Enacted by the Parliament of Republic of India by Notification in the Official Gazette. (Act 32 of 2003). 2003.

7 Government of India (GOI). National tobacco control programme 2007-2008. http ://www.mohfw.nic.in; 2008 [Accessed on August 15, 2018].

8 Global Research Priorities for Tobacco Control. Cohosted by Research for International Tobacco Control (RITC) and the World Health Organization. held in Washington, DC, USA: WHO); 1999.

9 International Institute for Population Sciences \& Macro International. National Family Health Survey, 2015-16. Mumbai: Mumbai IIPS; 2016.

10 Ministry of Health and Family Welfare (MoHFW) Government of India (GOI), International Institute for Population Sciences (IIPS). Global Adult Tobacco Survey India Report (GATS India), 2009-2010. Mumbai: Ministry of Health and Family Welfare, New Delhi; International Institute for Population Sciences; 2010.

11 Barros AJ, Hirakata VN. Alternatives for logistic regression in cross-sectional studies: an empirical comparison of models that directly estimate the prevalence ratio. BMC Med Res Methodol. 2003;3, 21 - 21.

12 Szklo M, Nieto FJ. Epidemiology: Beyond the Basics. second ed. Burlington: Jones \& Bartlett Learning; 2014.

13 Wacholder S. Binomial regression in GLM: estimating risk ratios and risk differences. Am J Epidemiol. 1986;123:174-184.

14 Schiaffino A, Rodriguez M, Pasarin MI, Regidor E, Borrell C, Fernandez E. [Odds ratio or prevalence ratio? Their use in cross-sectional studies]. Gac Sanit. 2003;17:70-74.

15 Brotman DJ. Mediators of the association between mortality risk and socioeconomic status. J Am Med Assoc. 2006;296:763-764. https://doi.org/10.1001/ jama.296.7.763-b. author reply 764 .

16 Watson GS. Smooth regression analysis. Sankhya. 1964;26:359-372.
17 Singh JK, Chiero V. Undernutrition in children in northeastern states, India: a district level geospatial analysis. Int J Sci Res. 2019;8(7). July - 2019, 2277 - 8179.

18 Krishnamoorthy Y, Ganesh K. Spatial pattern and determinants of tobacco use among females in India: evidence from a nationally representative survey. Nicotine Tob Res. 2020;22(12):2231-2237.

19 Karuppusamy B, Paulson W, Chellappan S, Behera SK, Nina PB. District-level epidemiology, hot spots and sociodemographic determinants of tobacco use in Indian men and women: analysis of national family health survey-4 (2015-16). Publ Health. 2021;194:127-134.

20 Singh JK, Singh N. Smokeless tobacco use among male and female in northeast state, India. Version 1.0 Global J Med Res. 2016;16(3). ISSN: 2249-4618. ISSN: 0975-5888.

21 Devi LJ, Laishram J, Laishram J, Devi M, Ingudum D. Tobacco use among females in an urban community of Imphal West, Manipur. IOSR J Humanit Soc Sci. 2013;11(5): 47-51.

22 Dasgupta A, Pal M, Paul B, Bandyopadhyay L. Predictors of smokeless tobacco consumption among women: a community based study in a slum of Kolkata. Int $J$ Commun Med Publ Health. 2018;5:1812-1816.

23 Singh S, Jain P, Singh PK, Reddy KS, Bhargava B. White paper on smokeless tobacco \& women's health in India. Indian J Med Res. 2020;151(6):513-521.

24 Mishra GA, Kulkarni SV, Gupta SD, Shastri SS. Smokeless tobacco use in urban Indian women: prevalence and predictors. Indian J Med Paediatr Oncol. 2015;36(3): 176-182.

25 Ladusingh L, Dhillon P, Narzary PK. Why do the youths in northeast India use tobacco? J. Environ. Publ. Health. 2017:6. https://doi.org/10.1155/2017/1391253. Article ID 1391253.

26 Bandyopadhyay TK, Som K, Thakur I, Paul R. Factors associated with tobacco use in female subjects: a study from eastern India. J Clin Diagn Res. 2019;13(2):28-33. 